\title{
Understanding For-Profit Higher Education in the United States Through History, Criticism, and Public Policy: A Brief Sector Landscape Synopsis
}

\author{
Matthew R. Hodgman (Corresponding author) \\ Department of Literature, American University \\ 4400 Massachusetts Avenue, NW, Washington, DC 20016, USA \\ Tel: 1-202-885-1000Ｅ-mail: hodgman80@hotmail.com
}

Received: June 20, 2018 Accepted: July 11, 2018 Published: July 14, 2018

doi:10.5296/jei.v4i2.13302ＵRL: https://doi.org/10.5296/jei.v4i2.13302

\begin{abstract}
Despite their uniquely innovative and long-standing history within the United States higher education landscape, for-profit higher education institutions (FPHEIs) remain controversial academic entities. Criticism of the for-profit sector maintains that these institutions are not preparing students for successful entry into the workforce. In light of numerous recent struggles, sector growth has significantly receded while FPHE practices and policies continue to be questioned. In the wake of sector decline, FPHEIs have an important opportunity to reimagine their role as educational providers to better serve students and society at large. At this critical transitional moment, this article briefly reviews the literature surrounding the overall FPHE landscape to date in terms of the historical background of the sector, criticisms leveled against FPHE, and important public policies surrounding the for-profit sector. Gaps in the FPHE landscape literature are noted and suggestions for additional sector research are offered with respect to generating future scholarship that may be useful when (re)considering the role that FPHEIs might assume going forward.
\end{abstract}

Keywords: For-profit higher education, Student outcomes, Non-traditional students, Public policy

\section{Introduction}

The vigorous growth of the FPHE sector in previous decades can be attributed to factors such as an auspicious business climate (Cottom, 2017; Deming et al., 2013), a business model that rapidly responds to market forces (Berg, 2005; Cottom, 2017), and the inability of other education sectors to provide career-oriented education (Bennett et al., 2010; Cottom, 2017; 
Douglass, 2012). Specifically, a focused curriculum, flexible scheduling, and diverse degree options associated with FPHEIs continue to make these institutions an attractive option, especially for nontraditional students.

Throughout this growth, FPHEIs have been consistently controversial institutions in higher education within the United States (Beaver, 2009; Deming et al., 2012, 2013; Dundon, 2015; Lechuga, 2008; Liu \& Belfield, 2014). There remains a stream of criticism aimed at FPHEIs claiming these institutions are not preparing students for successful entry into the workforce (Beaver, 2009; Deming et al., 2012, 2013; Dundon, 2015; Morse, 2015; Yeoman, 2011). Many question whether the profit motive is antithetical to providing a quality education (Beaver, 2009; Liu, 2011; Yeoman, 2011).

As FPHEIs face an industrial reset amidst precipitous declines in sector enrollment, this article offers a brief overview of the literature surrounding the overall FPHE landscape to date in hopes of ultimately noting gaps in the research and providing suggestions for further needed sector research. The literature concerning the FPHE landscape is explored through the following key areas: (a) the historical background of FPHEIs, (b) criticisms against the for-profit sector, and (c) public policies concerning FPHEIs.

\section{Historical Background of FPHEIs}

\subsection{Educating Marginalized and Nontraditional Populations}

FPHE is not a new phenomenon; it has existed in various forms for over 300 years. FPHEIs, unlike traditional institutions, do not typically provide students with a liberal education or prepare students to continue within higher education as, for example, community colleges do. Rather, they primarily offer training for a vocation or trade (O’Malley, 2012).

FPHE was often considered the only option for many marginalized and nontraditional students who wanted a career education instead of the liberal classical education offered at traditional institutions during the colonial and antebellum eras in America. Career education catered to professions, such as business, farming, and engineering, that were not accommodated for in classical, denominational colleges (Berg, 2005; Geiger, 2000; Ruch, 2001). FPHEIs during the 19th century were noted for providing access to education for marginalized peoples, such as Blacks, Native Americans, the blind and deaf, and women, and for students who did not seek a traditional education (Geiger, 2000; Kinser, 2006; Ruch, 2001). For example, from 2011 to 2012 , women constituted $60 \%$ to $76 \%$ of undergraduates attending FPHEIs, compared with $54 \%$ to $57 \%$ of students at public or nonprofit institutions (National Center for Education Statistics, 2017). In addition, from 2011 and 2012, 22\% to $27 \%$ of students at FPHEIs were Black, compared with $13 \%$ to $16 \%$ at public or nonprofit institutions (National Center for Education Statistics, 2017).

The for-profit sector today educates a large population of nontraditional students (e.g., populations of color, students who work full-time, adult learners or individuals 25 years of age or older) and encompasses a vast array of institution types in terms of geographic scope (e.g., enterprise or multicampus institutions), ownership (i.e., privately or publicly held), and level of degree granted (certificates to doctoral degrees; Floyd, 2007; Kinser, 2006). FPHE 
programs range from healthcare and business to cosmetology and dog grooming. Most of the credentials earned in the for-profit sector are certificates; certificates accounted for $54 \%$ of the awards conferred by FPHEIs in the 2008-2009 academic year (Deming et al., 2012).

FPHEIs disproportionately serve adult learners, Hispanics, and Blacks. At 4-year institutions, Blacks account for $30 \%$ of students at FPHEIs and account for only $12 \%$ and $13 \%$ of students at public and nonprofit private institutions, respectively (National Center for Education Statistics, 2013). At 2-year institutions, Hispanics account for $24 \%$ of students at FPHEIs, where they account for $22 \%$ and $13 \%$ of students at public and private nonprofit institutions, respectively (National Center for Education Statistics, 2013). FPHEIs account for just over $7 \%$ of the overall undergraduate enrollment at degree-granting postsecondary institutions, yet they enroll $15 \%$ of Blacks and $7 \%$ of Hispanics attending these institutions (National Center for Education Statistics, 2014). At 4-year FPHEIs, 70\% of students are 25 years or older, whereas just $12 \%$ of students at 4 -year public colleges and $13 \%$ of students at 4 -year private nonprofit colleges are older than 25 (National Center for Education Statistics, 2013).

\subsection{Focus on Business}

As they do today, the first for-profit institutions offered a practical education designed to give students the skills necessary for trade and commerce. For-profit business schools emerged in the early 19th century. The first business school advertisement was published by James Gordon Bennett in 1824, and the first business "college" (Bartlett's Commercial College) was opened in 1834 by R. Montgomery Bartlett (Kinser, 2006). This school was the first for-profit institution of its kind to use the word "college" (Reigner, 1959). Practical business education signaled a marked deviation from the findings of the influential Yale Report of 1828, which defended the classical curriculum on the grounds that it provided the discipline of the mental faculties needed to be respected members of society (Geiger, 2000). From the 1850s to the $1890 \mathrm{~s}$, for-profit business education held a virtual monopoly on business education and expanded from an estimated 20 colleges in 1850 to at least 250 institutions enrolling more than 81,000 students in 1890 (Kinser, 2006). Today, although 5\% of all bachelor's degrees are granted by for-profit institutions, $12 \%$ of all bachelor's degrees in business, management, and marketing are granted by FPHEIs (Deming et al., 2012).

\subsection{Current Corporate Era}

The for-profit sector today operates in a corporate era in which large publicly traded corporations have driven the expansion of the sector (Bankston, 2011; Floyd, 2007; Kinser, 2006; Ruch, 2001). These large national companies are financialized, meaning that their operations are embedded in the norms and practices of the financial sector with a corporate structure designed to protect shareholder interests (Cottom, 2017). The 1994 initial public offering (IPO) of the Apollo Group (parent company to the University of Phoenix) was the first IPO in the FPHE sector. Furthermore, in the mid-1990s, private investment capital began to swiftly flow into the business of education. Also, under the 1992 reauthorization of the Higher Education Act (HEA), the Integrated Postsecondary Education Data System (IPEDS) changed the definition of higher education, and FPHEIs were included as eligible for federal financial aid programs (Ruch, 2001). After FPHEIs became eligible for Title IV funding, 
which includes funds from federal student aid programs administered by the U.S. Department of Education, the sector saw unbridled increases in student enrollment. Between 1998 and 2008 , the enrollment at FPHEIs grew by $225 \%$ as sector enrollment grew from 766,000 students to 2.4 million students (Lee, 2012).

The FPHE sector contains the largest schools by enrollment in the United States. In the Fall 2012 term, for example, the University of Phoenix online campus enrolled over 256,000 students, Ashford University enrolled over 77,000, and American Public University enrolled over 58,000 (National Center for Education Statistics, 2013). The 23 largest for-profit institutions enrolled more than 1.1 million students in 2012 and accounted for nearly $20 \%$ of the growth of U.S. bachelor's degrees from 2002 to 2012 (Deming et al., 2014). The for-profit sector has become synonymous with the large national institutions that have rapidly expanded their presence in the undergraduate and graduate education markets.

In terms of cost, on average, FPHEIs cost more to attend than both two-year and four-year public, non-profit institutions and much less to attend than private, non-profit institutions. On average, the cost to attend four-year public institutions for students enrolled in state is $\$ 9,970$, two-year public institutions for students enrolled in state cost $\$ 3,570$, four-year private institutions cost on average $\$ 35,260$, and for-profit institutions cost $\$ 16,000$ on average (College Board, 2017).

\subsection{Factors Supporting the Rise of FPHEIs}

The proliferation of for-profit institutions marks a noteworthy split within higher education. As Tierney and Hentschke (2007) suggest, FPHEIs can currently be viewed as "splitters" from traditional academia in terms of their profit-seeking behavior, career-focused curricula, and use of innovative technology (p. 2). As splitters, FPHEIs have revolutionized the higher education industry; the for-profit sector has cultivated and catered specifically to a new market of consumers, namely nontraditional college students, and has used technological and scheduling innovations (e.g., relating to virtual education, course offerings, and academic calendar structures) to satisfy students who have different educational needs (i.e., need for career-oriented education) than traditional college students at nonprofit institutions.

FPHEIs have thrived in a new economy that demands the constant, quick, and consistent retraining of workers at little to no expense for employers. Cottom (2017) explains that this new economy is marked by four economic shifts: (a) people frequently changing jobs and employers over their lifetimes (job mobility); (b) employers placing greater reliance on contract, term, and temporary labor (labor flexibility); (c) less reliance on employers for income growth and career progression (declining internal labor markers); and (d) workers shouldering more responsibility for their job training, healthcare, and retirement (risk shift). Under this new economy, FPHEIs propagated a narrative counter to the one that claimed eroding job conditions are evidence of the failure of higher education. Instead, FPHEIs convinced regulators and investors that eroding job conditions were profitable for higher education in that sector institutions could gain from a job crisis by catering to students who were not being served by traditional institutions and could borrow money for tuition even though they had the least amount of assets and the fewest college choices (Cottom, 2017). 
FPHEIs also proliferated by placing themselves as important entities within the context of the "education gospel" or the idea that higher education is a moral good because it serves market interests (Cottom, 2017, p. 11). Based on the education gospel, individuals are increasingly expected to sacrifice to pursue higher education with more loans, more risk of attainment, fewer grants, and fewer practical options in order to attain educational credentials that will help advance them in the labor force. The existence of FPHEIs supports the idea that education is good because a job is good (Cottom, 2017). However, credential expansion through FPHEIs in the name of the education gospel and within the parameters of the new economy has targeted vulnerable groups, such as single mothers, downsized workers, veterans, and people of color, exclusively for profit (Cottom, 2017). Conditions under the education gospel and new economy produce career and life aspirations that are only viable by gaining more credentials in perpetuity, and so individuals not being served by traditional institutions have turned to FPHEIs for those credentials (Cottom, 2017).

FPHEIs, led primarily by on-line institutions, experienced remarkable growth over the past several decades. FPHEIs enroll over 3 million students in a wide variety of career programs. In the period between 1986 and 2009, enrollment within FPHEIs grew from $2 \%$ of all students to more than $10 \%$ of all students enrolled in institutions of higher education (Liu, 2011). The percentage of undergraduates attending FPHEIs more than doubled between 1995 and 2012, from 5\% to $13 \%$ overall and from 1\% to 17\% in 4-year FPHEIs (National Center for Education Statistics, 2017). In 2012, more than 13\% of undergraduates attended FPHEIs, up from 9\% in 2009 (Deming et al., 2012). The rapid growth of the FPHE sector has been attributed to several factors. More individuals in the United States were graduating from high school in the early 2000s than ever before, yet unequal K-12 schools created a market of college-going students while also creating inequalities among students' abilities to meet the admissions criteria at traditional institutions (Cottom, 2017). FPHEIs have catered to the increasing need for workers with new skill sets and credentials in an increasingly global and knowledge-based service economy by offering programs that openly admit and prepare students from all educational backgrounds for high-demand work fields such as those in the corporate sector (Berg, 2005; Ruch, 2001). This model has allowed FPHEIs to rapidly respond to the marketplace and offer innovative career-oriented programs that fit conveniently within students' busy lives. The rapid nature of the model has allowed FPHEIs to successfully appeal to students seeking credentials at all educational levels (i.e., sub-baccalaureate, bachelor's, graduate, professional) by maximizing time; time is a commodity that FPHEIs value over institutional prestige (Cottom, 2017). Finally, a policy climate that favored private enterprise and the inability of other sectors to provide career-specific training helped escalate the growth of FPHEIs (Bennett et al., 2010; Berg, 2005; Deming et al., 2013; Douglass, 2012; Fain \& Lederman, 2015; Ruch, 2001). Neoliberal ideas of individualism, markets, and profit taking bolstered FPHEIs as regulations guaranteed them access to federal student aid programs and relatively little competition for the workers who had few options if they wanted a good job (Beaver, 2009; Cottom, 2017). Should sector credentials not lead to good jobs, the neoliberal ideas of individualism and personal responsibility absolved FPHEIs of any wrongdoing (Cottom, 2017). Demand for the occupational degrees and certificates offered by FPHEIs will likely remain strong. Compared 
to students who earned academic credentials (e.g., credentials earned in the fields of English, foreign languages, history, liberal arts, mathematics, philosophy, science, social sciences, and theology), a higher proportion of students who earned occupational credentials (e.g., credentials earned in the fields of agriculture, business management, communications, computer sciences, construction, engineering, health sciences, manufacturing, social services, transportation, and performing arts) were employed in 2009 and among employed completers (i.e., students who earned a credential), a higher proportion of those with occupational credentials reported working in a job related to their field of study compared to those with non-occupational academic credentials (National Center for Education Statistics, 2016). This employment reality illuminates the positive potential and need for FPHEIs which almost exclusively offer occupational credentials. Despite significant growth and the benefit of occupational credentials, the sector has been heavily criticized.

\section{Criticism of FPHEIs}

Scrutiny of the for-profit sector has been prevalent. Institutions have been criticized for employing deceptive recruiting and marketing techniques (Bennett et al., 2010; Deming et al., 2012), saddling students with large debt burdens (Deming et al., 2012), leaving students with high student loan default rates (Deming et al., 2012), creating job placement issues (Chait, 2011), and producing low graduation rates (Bennett et al., 2010; Chait, 2011; Deming et al., 2012, 2013; Dundon, 2015; Hacker \& Dreifus, 2010; Heller, 2011; Liu, 2011).

\subsection{Recruiting and Marketing Techniques}

FPHEIs have been accused of employing deceptive marketing, recruiting, and retention-centered practices (Bennett et al., 2010; Deming et al., 2012, 2013; Yeoman, 2011). At one institution, for example, recruiters were encouraged to misrepresent teacher qualifications, job placement statistics, potential salaries upon graduation, and whether credits would transfer to other postsecondary education institutions (Yeoman, 2011). FPHEIs have offered their recruiters financial incentives based on the quantity of students recruited within a specified period of time (Deming et al., 2012). Practices such as these have suggested to some that these institutions are more concerned with profits than with educational quality (Berg, 2005; Liu, 2011).

\subsection{Student Borrowing and Loan Defaults}

Student borrowing and loan default rates have been high for students enrolled in the FPHE sector. According to a 2015 study by the Woodstock Institute, students at 2-year FPHEIs were nearly $50 \%$ more likely to borrow than students at 2-year public colleges, all other factors being equal. Students who took out debt borrowed $\$ 1,300$ more on average to attend 2-year FPHEIs than to attend 2-year public colleges. In terms of student borrowing demographics, Latino and White students at 4-year FPHEIs were significantly more likely to borrow than Latino and White students at public or nonprofit schools (Woodstock Institute, 2015). The cohort default rate is defined as the share of borrowers at each school who enter into repayment on federal loans during a 12-month period and subsequently default in the next 2 (or 3) years. Institutions with a 2 -year cohort default rate that exceeds $40 \%$ in 1 year, or $25 \%$ 
for 3 consecutive years, should lose their eligibility for Title IV aid for 1 to 3 years (National Archives and Records Administration, n.d.). Three-year cohort default rates for fiscal year 2008 were $24.9 \%$ for for-profits, $10.8 \%$ for public institutions, and $7.6 \%$ for private nonprofits (Steinerman, Volshteyn, \& McGarrett, 2011). These statistics combined with poor sector graduation rates, 54\% of FPHE students complete certificate programs within 6 years and only $26 \%$ of students seeking bachelor's degrees complete within 6 years (Deming et al., 2013), have prompted questions as to whether FPHEIs are hurting the students they purport to help (Deming et al., 2013; Liu, 2011; Liu \& Belfield, 2014; Morse, 2015).

\subsection{Job Placement Rates and Institutional Deception Regarding Job Placements}

FPHEIs have been accused of not graduating students and providing deceiving records concerning job placement. Low sector graduation rates and a lack of reliable FPHE job placement data raise questions as to whether employers are willing to hire graduates of for-profit schools.

\subsubsection{Institutional Deception Regarding Job Placements}

Some FPHEIs have adjusted their job placement records to present an inaccurate and disingenuous picture of job placement outcomes (Burd, 2014; Yeoman, 2011). Many FPHEIs have admitted to considering graduates successfully placed if those graduates accepted any job after graduation, including jobs that were not within the graduate's intended field of study or jobs that did not require an academic credential (Burd, 2014). For example, some students at institutions have been considered successfully placed in a business career if they took entry-level positions at national chain restaurants that did not require educational credentials beyond a high school diploma (Burd, 2014). Situations such as this raise questions as to the job FPHEIs are doing in placing students in relevant career fields.

\subsubsection{Job Placement Rates}

Employers have expressed beliefs that for-profit credentials do not give graduates any added value in the job market, and data show that sector graduates experience higher unemployment rates and lower earnings 6 years after entering programs than do graduates from traditional institutions (Deming et al., 2012, 2013).

Despite these claims, there is no consensus as to whether sector graduates fare well in the labor market in terms of the likelihood that they will be employed, for how long, at what time, and in what kind of occupation (Cottom, 2017). Job placement rates are unreliable and mutable since a standard methodology in calculating job placement rates has not been federally established. Sector job placement rates are determined by accreditation agencies and states and as a result, the methodologies vary state by state and accreditor by accreditor making them impossible to objectively compare. FPHEIs have a large amount of discretion when it comes to determining which students they include in their calculations, and this could allow FPHEIs to inflate job placement rates to make their institutions more attractive to potential students (Burd, 2014). For example, some institutions may report different job placement rates to their national accreditors than they do to state agencies; this practice has led to confusion as to which metric, if any, is accurate (Fain, 2015). 


\section{Public Policies Concerning FPHEIs}

Access to federal aid dollars ushered in allegations of abuse within the for-profit sector that prompted external oversight of institutional activities. Certain FPHEIs were accused of student loan abuses and marketing and recruiting improprieties in order to make quick gains from federal aid distributions (Bennett et al., 2010; Deming et al., 2013; Kinser, 2006). In response, federal policies were developed (mainly through the 1992 reauthorization of the Higher Education Act) to provide restrictions on the establishment of new branch campuses and ban the use of incentive compensation structures for admissions officials (Deming et al., 2012, 2013). It is important to understand policies surrounding FPHEIs to gain an understanding of attempts made to combat criticisms of FPHEIs, better use federal dollars, and increase the quality of for-profit higher education. The 90/10 rule, cohort default rates, and gainful employment legislation are the most prominent polices currently in place; these policies concern institutional eligibility for federal (mainly Title IV) student financial aid.

\subsection{The 90/10 Rule}

Federal student financial aid is the lifeblood of for-profit higher education in the United States. The 90/10 rule attempts to ensure that FPHEIs are no more than $90 \%$ dependent on Title IV federal student aid as a share of their total revenues. The logic behind the rule is that FPHEIs should not be funded solely by federal taxpayers. FPHEIs get an average of $71.5 \%$ of their revenue from Title IV federal student aid programs; if an individual institution exceeds the $90 \%$ limit, the result is a loss of eligibility for federal funds (Institute for College Access and Success, 2015). It is important to note that GI Bill monies are not counted toward the $90 \%$ of revenues allowed from federal financial aid sources.

\subsection{Cohort Default Rates}

Institutional cohort default rates measure the share of an institution's federal student loan borrowers who default within a 2- or 3-year time period after entering repayment. This policy highlights institutions that may be preying on low-income students who might have trouble repaying their loans. FPHEIs have disproportionately high sector default rates when compared to public and private nonprofit institutions. The cohort default rate is $7.2 \%$ for private nonprofit institutions, $12.9 \%$ for public colleges, and $19.1 \%$ at FPHEIs, which have historically had the highest default rates (Bidwell, 2014).

\subsection{Gainful Employment}

Under gainful employment regulation, aimed specifically at FPHEIs, a program is considered to lead to gainful employment if at least $35 \%$ of the students in each cohort year are in repayment of their federal loans or if the annual loan payment for a typical student is $12 \%$ or less of his or her annual earnings or $30 \%$ or less of his or her discretionary income (Deming et al., 2012). These regulations are designed to ensure that programs advertising pathways to jobs actually lead to said jobs (Cottom, 2017). Gainful employment regulations require institutions to provide information such as what a typical graduate earns, how much debt graduates have, and what share of students graduate and find employment in their specified fields; new regulations will also require institutions to disclose their program costs and 
student loan repayment rates (Protect Students and Taxpayers, 2015).

Such regulations enforce the HEA's requirement that all career education programs receiving federal student aid prepare students for gainful employment in an occupation (Protect Students and Taxpayers, 2015). The expectation of gainful employment seeks to hold FPHEIs more accountable and put a greater burden on the colleges rather than only on students. Under this policy, institutions that do not meet gainful employment standards will lose access to federal student aid monies. This policy, it is believed, will help make FPHE programs more effective (Protect Students and Taxpayers, 2015).

\section{Summary, Gaps, and Additional Research}

This section summarizes the FPHE landscape literature discussed above, outlines gaps that exist in the literature, and puts forth suggestions for future research to fill these gaps.

\subsection{Summary of the FPHE Literature}

The literature on the landscape of FPHEIs lays a foundation and provides a context for understanding the nature of these institutions, the factors undergirding their rapid growth, the challenges they face, and the policies that impact the for-profit sector. The literature informs us that for-profit higher education has existed in some form for centuries. FPHEIs currently exist in many forms and cater predominantly to racial minorities and nontraditional students. For-profit schools have focused on providing students with practical skills that are intended to translate into success in the workplace. The first FPHEIs were primarily business schools that taught a career-oriented curriculum that deviated distinctly from the liberal classical curriculum of traditional colleges and universities. Business has been the primary work field that FPHEIs have catered to throughout the history of these institutions. The current era of for-profit higher education can be viewed as a corporate era in which large publicly held institutions are the most visible players within the sector.

The rapid rise of FPHEIs can be attributed to a number of factors, including a favorable business climate, a focus on enrolling nontraditional students, a business model that creatively and rapidly responds to the marketplace, and the inability of other sectors to provide career-oriented training. Despite their economic success, FPHEIs have been criticized for the way they do business. Accusations, such as employing deceptive marketing and recruiting tactics, loading students with large debt burdens, producing high student loan default rates, and creating poor employment outcomes for students, have created a stigma against the for-profit sector. Federal policies, such as 90/10, cohort default rates, and gainful employment, have attempted to address bad actors; however, a sector stigma based on the aforementioned criticisms may influence the way the sector and its graduates are perceived.

\subsection{Gaps in the Literature}

The FPHE landscape literature is nascent and numerous voids exist. In particular, the following gaps are emphasized below: the infancy of the sector landscape literature, the limited nature of the FPHE landscape literature, the minimal literature concerning employers' perceptions of FPHE institutions, and the limited demographics and programs included in 
sector research.

The FPHE landscape literature is young, with literature published on the for-profit higher education sector first appearing in 2005. The emergence of literature surrounding FPHEIs coincided with the rise of large publicly held institutions and a litany of criticism of how these institutions did business. Sanctions against large FPHEIs (such as the University of Phoenix), the close of several institutions, and government-backed statistical data on student loan default rates and program completion rates prompted researchers to analyze the landscape of the FPHE sector and potential reasons behind sector shortcomings.

Additionally, the literature is limited; few comprehensive empirical research studies have focused solely on FPHEIs. Deming et al. (2012, 2013) and Douglass (2012) explored the FPHE landscape along several variables but with a focus on comparing FPHEIs to other institutions such as community colleges. Limited research focuses solely on FPHEIs without comparing these institutions to other higher education sectors.

There is a limited body of research surrounding the FPHE landscape that employs qualitative research methodologies. Quantitative studies are more prevalent. For example, Deming et al. (2012, 2013) and Liu and Belfield (2014) used quantitative methodologies to evaluate educational quality at FPHEIs; statistical analysis is common within research concerning FPHEIs. Studies such as Lechuga (2008), and Bennett et al. (2010) employed qualitative methodologies such as case study and interview approaches. The Bennett et al. study used a mixed methods approach where statistical analyses were used to derive interview questions for a qualitative approach. Few studies solely employed a qualitative approach.

Finally, few studies have been conducted that focus on specific FPHE programs such as healthcare or business. There is limited sector literature that is related to a particular FPHE programmatic offering and field of work (e.g., business) and to a particular sector population (e.g., recent FPHE undergraduate business program graduates).

\subsection{Need for Additional Research}

The FPHE landscape literature is lacking in terms of methodological considerations, research topics, and participant samples. In terms of methodology, additional research is needed that employs specific qualitative approaches and explains results in specific conceptual contexts. The literature could benefit from studies that give qualitative insight into several aspects of for-profit higher education such as the study conducted by Lechuga (2008) on faculty work at FPHEIs. A majority of the research surrounding for-profit higher education is descriptive or quantitative in nature and does not provide in-depth analysis of the many voices connected to this sector. This methodological gap might be filled through a qualitative study examining the perceptions of the programmatic quality of FPHE healthcare programs from the perspective of the graduates themselves.

In terms of research topic and sample, there is a need for research that focuses on different aspects of sector outcomes through the eyes of different populations. For example, research is needed relative to how FPHEIs are performing from the vantage point of different stakeholders (Jez, 2014). These areas might be explored by looking at different types of 
FPHEIs (e.g., publicly versus privately held institutions), focusing on different participant demographics (e.g., Black FPHE students or sector business students), or by analyzing some of the different sector programs (e.g., healthcare or business). More specifically, there is a need for research that explores the voices and experiences of FPHE students. A qualitative research project that explores perceptions of the quality of FPHE and perceptions of satisfaction with the outcomes of attending sector institutions from the perspectives of current and former FPHE students would add significantly to the overall sector research both in terms of research methodology and content. Student perceptions of the sector are important and lacking in the current FPHE literature; these perceptions will provide important data that important sector stakeholders such as administrators can refer to when considering action in terms of increasing sector quality.

In addition, in terms of research that focuses solely on FPHE, more research is needed that does not simply compare the for-profit sector to other more traditional higher education students and sectors. Student cohorts from disadvantaged and poorly qualified groups such as students in the FPHE sector cannot be expected, on graduation, or even during performance, to compare with more qualified input groups such as students at private, non-profit higher education institutions. Future research in this capacity might focus on the FPHE sector in terms of how future FPHE sector cohorts make progress toward graduation and job placement etc. against previous sector cohorts or on what FPHE administrators are doing specifically to increase sector quality along a numbers of metrics such as job placement or FPHE student experiences.

In conclusion, the FPHE landscape literature has numerous gaps. The previous discussion highlighted gaps concerning the infancy of the literature and the limited nature of the literature. Methodological deficiencies exist as demonstrated through a lack of qualitative studies. Content deficiencies exist as the literature is in need of studies on the performance of FPHEIs. The content of future studies needs to focus on different FPHE programs and populations to expand the literature.

\section{References}

Bankston, C. L., III. (2011). The mass production of credentials: Subsidies and the rise of the higher education industry. The Independent Review, 15(3), 325-349.

Beaver, W. (2009). For-profit higher education: A social and historical analysis. Sociological Viewpoints, 25, 53-73.

Bennett, D. L., Lucchesi, A. R., \& Vedder, R. K. (2010). For-profit higher education: Growth, innovation, and regulation. Retrieved from http://www.centerforcollegeaffordability.org/ uploads/ForProfit_HigherEd.pdf

Berg, G. A. (2005). Lesson from the edge: For-profit and nontraditional higher education in America. Westport, CT: Praeger.

Bidwell, A. (September 24, 2014). Student loan default rate drops 7 percent in one year. U.S. News and World Report. Retrieved from http://www.usnews.com/news/articles/2014/09/24/ 
student-loan-default-rate-decreases-but-some-question-federal-free-passes

Burd, S. (February 20, 2014). New disclosures show what's wrong with for-profit college job placement rates. Retrieved from http://www.edcentral.org/new-gainful-employment-datashows-whats-wrong-profit-college-job-placement-rates

Chait, J. (2011). The diploma factories. New Republic, $242(4), 2$.

College Board. (2017). Trends in College Pricing 2017. Retrieved from https://trends. collegeboard.org/sites/default/files/2017-trends-in-college-pricing_0.pdf

Cottom, T. M. (2017). Lower ed: The troubling rise of for-profit-colleges in the new economy. New York: The New Press.

Deming D. J., Goldin, C., \& Katz, L. F. (2012). The for-profit postsecondary school sector: Nimble critters or agile predators? Journal of Economic Perspectives, 26(1), 139-164. https://doi.org/10.1257/jep.26.1.139

Deming D. J., Goldin, C., \& Katz, L. F. (2013). For-profit colleges. Future of Children, 26(1), 137-163. https://doi.org/10.1353/foc.2013.0005

Deming, D. J., Yuchtman, N., Abulafi, A., Goldin, C., \& Katz, L. F. (2014). The value of postsecondary credentials in the labor market: An experimental study (Working Paper No. 20528). Washington, DC: The National Bureau of Economic Research. https://doi.org/ $10.3386 /$ w 20528

Douglass, J. A. (2012). The rise of the for-profit sector in US higher education and the Brazilian effect. European Journal of Education, 47(2), 242-259. https://doi.org/10.1111/ j.1465-3435.2012.01521.x

Dundon, M. (2015). Students or consumers? For-profit colleges and the practical and theoretical role of consumer protection. Harvard Law and Policy Review, 9(2), 375-401.

Fain, P. (April 17, 2015). Regulating job placement. Retrieved from https://www.inside highered.com/news/2015/04/17/feds-take-down-profit-over-job-placement-rates-gainful-empl oyment-rules-loom

Fain, P., \& Lederman, D. (2015). Boom, regulate, cleanse, repeat: For-profit colleges' slow but inevitable drive toward acceptability. In M. W. Kirst \& M. L. Stevens (Eds.), Remaking college: The changing ecology of higher education (pp. 61-83). Stanford, CA: Stanford University Press.

Floyd, C. E. (2007). Know your competitor: Impact of for-profit colleges on the higher education landscape. New Directions for Higher Education, 140, 121-129. https://doi.org/ 10.1002/he. 286

Geiger, R. L. (Ed.). (2000). The American college in the nineteenth century. Nashville, TN: Vanderbilt University Press.

Hacker, A., \& Dreifus, C. (2010). Higher education? How colleges are wasting our money 
and failing our kids-and what we can do about it. New York, NY: St. Martin's Griffin.

Heller, D. E. (2011). The impact of gainful employment regulations. Change, 43(5), 58-64. https://doi.org/10.1080/00091383.2011.607074

Institute for College Access and Success. (July 25, 2015). Q\&A on the for-profit college “90-10 rule". Retrieved from http://ticas.org/sites/default/files/pub_files/90-10_qa_0.pdf

Jez, S. J. (April 28-29, 2014). What data exist that might be useful to do research on for-profits? Paper presented at the USC symposium on for-profit higher education. Los Angeles, CA: University of Southern California.

Kinser, K. (2006). From main street to Wall Street: The transformation of for-profit higher education. San Francisco, CA: Jossey-Bass.

Lechuga, V. M. (2008). Assessment, knowledge, and customer service: Contextualizing faculty work at for-profit colleges and universities. The Review of Higher Education, 31(3), 287-307. https://doi.org/10.1353/rhe.2008.0004

Lee, S. (August 13, 2012). The explosive growth of for-profit higher education, by the numbers. Retrieved from http://www.motherjones.com/media/2012/08/explosive-growthprofit-higher-education-numbers

Liu, M. C. (2011). Do for-profit schools pass the test? State Legislatures, 37(6), 15-17.

Liu, Y. T., \& Belfield, C. (2014). Evaluating for-profit higher education: Evidence from the education longitudinal study. Center for Analysis of Postsecondary Education and Employment. Retrieved from http://ccrc.tc.columbia.edu/media/k2/attachments/capseeevaluating-for-profit-els.pdf

Morse, S. N. (2015). For-profit schools: A history of abuse and the need for reform. Brigham Young University Education \& Law Journal, 2, 585-595.

National Archives and Records Administration. (n.d.). Amendments to the Higher Education Act, 34 CFR 668.187(a). Electronic Code of Federal Regulations. Retrieved from http://ecfr.gpoaccess.gov/cgi/t/text/text-idx?c=ecfr\&rgn=div5\&view=text\&node=34:3.1.3.1.3 $4 \&$ idno $=34$

National Center for Education Statistics. (2013). The condition of education 2013. Retrieved from http://nces.ed.gov/programs/coe/indicator_cha.asp

National Center for Education Statistics. (2014). Total fall enrollment in degree-granting postsecondary institutions, by control and level of institution, level of enrollment, and race/ethnicity of student: 2014. Retrieved from https:/nces.ed.gov/programs/digest/d15/ tables/dt15_306.50.asp?current=yes

National Center for Education Statistics. (2016). Employment status of postsecondary completers in 2009: Examination of credential level and occupational credentials. Retrieved from http://nces.ed.gov/pubsearch/pubsinfo.asp?pubid=2016107 


\section{Macrothink}

National Center for Education Statistics. (2017). A profile of the enrollment patterns and demographic characteristics of undergraduates at for-profit institutions. Retrieved from https://nces.ed.gov/pubsearch/pubsinfo.asp?pubid=2017416

O'Malley, S. (2012). The leading edge of corporatization in higher ed: For-profit colleges. Thousand Oaks, CA: Sage.

Protect Students and Taxpayers. (June 30, 2015). Gainful employment rule questions and answers. Retrieved from http://www.protectstudentsandtaxpayers.org/wp-content/uploads/ 2015/06/GainfulEmploymentQA_June-30-2015-_5-pages.pdf

Reigner, C. G. (1959). Beginnings of the business school. Baltimore, MD: Rowe.

Ruch, R. S. (2001). Higher ed. inc.: The rise of the for-profit university. Baltimore, MD: Johns Hopkins University Press.

Steinerman, A., Volshteyn, J., \& McGarrett, M. (2011). In J. P. Morgan (Ed.), Education services data book. North American Equity Research, Business and Education Services.

Tierney, W. G., \& Hentschke, G. C. (2007). New players, different game: Understanding the rise of for-profit colleges and universities. Baltimore, MD: Johns Hopkins University Press.

Woodstock Institute. (2015). Starting out behind: Trends in student loan burdens at for-profit colleges. Retrieved from http://www.woodstockinst.org/research/starting-out-behind-trendsstudent-loan-burdens-profit-colleges

Yeoman, B. (2011). The high price of for-profit colleges. Academe, 97(3), 32-37.

\section{Copyright Disclaimer}

Copyright for this article is retained by the author(s), with first publication rights granted to the journal.

This is an open-access article distributed under the terms and conditions of the Creative Commons Attribution license (http://creativecommons.org/licenses/by/3.0/). 